\title{
Accounting Department Chairpersons' Perceptions Of Business School Performance Using A Market Orientation Model
}

Robert L. Webster, Ouachita Baptist University, USA

Kevin L. Hammond, University of Tennessee at Martin, USA

James C. Rothwell, Ouachita Baptist University, USA

\begin{abstract}
This manuscript is part of a stream of continuing research examining market orientation within higher education and its potential impact on organizational performance. The organizations researched are business schools and the data collected came from chairpersons of accounting departments of AACSB member business schools. We use a reworded Narver and Slater (1990) "market orientation" scale and the Jaworski and Kohli's (1993) "overall performance" scale for use in the current research. 101 chairs of accounting departments whose schools are members of AACSB responded to the survey. The manuscript details the data collection and analysis processes, the statistical findings, along with implications and a call for additional subject matter research.
\end{abstract}

Keywords: AACSB-International; Business School Performance; Markets; Market Orientation; Higher Education

\section{INTRODUCTION}

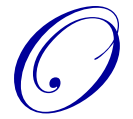

rganizations of all forms seek to attain and maintain high levels of performance. In the world of business schools, superior performance is often equated to accreditation by independent bodies such as AACSB - International (AACSB). However, an often asked question is whether a particular organizational strategy or culture can lead to improved organizational performance? And, if so, can such a strategy or culture be described and then be measured quantitatively? This research investigates these questions and attempts to provide insight into how performance perceptions of business schools belonging to AACSB may be influenced by a particular culture or strategy, in this study, market orientation.

AACSB standards for business school accreditation outline requirements that if met lead to accreditation thereby elevating the status of the school as well as indicating superior performance. Additionally, the Baldrige National Quality Program (BNQP 2005) has established the Baldrige Education Criteria for Performance Excellence for universities and other educational organizations, and includes a "student, stakeholder, and market focus category" (BNQP 2005) among the criteria leading to performance excellence. This particular category of criteria suggests that organizations identify potential market segments and determine which ones to pursue, then take steps to learn "key requirements and changing expectations," build relationships, increase loyalty, and determine satisfaction/dissatisfaction of those student/stakeholder markets. The focus category also emphasizes the importance of strategic decisions regarding the extent that university business schools may choose to focus on particular markets, and the balance of focus between chosen markets. These decisions may obviously contribute to the culture of the school, encouraging or discouraging attentiveness to students and potential students, parents of students, future employers of graduates, and other stakeholder markets. 
Marketing literature describes market orientation as an organizational culture in which everyone in the organization is committed to the customer and adapts in a timely manner to meeting the changing needs of the customer. Market orientation blends a company culture dedicated to providing superior value with successfully achieving a customer focus, acquiring competitor intelligence, and maintaining interfunctional coordination. It is viewed as the implementation of the marketing concept.

The idea that organizations of higher education should employ marketing strategies to improve their performance appeared in the literature as early as the 1960s. Kotler and Levy (1969) were pioneers in successfully arguing for broadening the scope of marketing (and the marketing concept) to include higher education as well as other nonbusiness organizations. Market selection and other applications of marketing theory by practitioners within higher education therefore seem appropriate and should certainly be beneficial.

This paper reports the results of an empirical study within AACSB member business schools examining the levels of self-reported market orientation toward students. Market orientation variables are measured and are used as the independent variables in this study. The research then investigates the impact of the independent variables on reported organizational performance, the dependent variable in the study. Although there are many possible customer groups that might be of interest within the context of market orientation within higher education, this paper limits the customer group to students.

\section{DISCUSSION AND LITERATURE REVIEW}

In accounting and in the other business disciplines, excellence is assessed and assured by the qualification standards of the bodies awarding formal accreditation to accounting programs and business schools (Karathanos and Karathanos 1996). For American business schools, the main accreditation body is AACSB-International (the Association to Advance Collegiate Schools of Business). Performance is ranked more informally in the U.S.A. by the annual guide published by U.S. News and World Report and by the Peterson's web-based educational information resource, both directed at prospective students, their parents and their advisers.

The BNQP (2005), mentioned above, incorporates behaviors and actions indicative of high levels of market orientation as described in the marketing literature (Kohli and Jaworski 1990; Narver and Slater 1990; Jaworski and Kohli 1993; Slater and Narver 1994; Webster, Hammond, and Harmon 2005; Hammond, Webster, and Harmon 2006) throughout the education criteria for performance excellence. Further, marketing literature (Barksdale and Darden 1971; Houston 1986; Kohli and Jaworski 1990; Narver and Slater 1990; Jaworski and Kohli 1993; Siguaw, Brown, and Widing 1994) supports assertions by practitioner-oriented publications such as the BNQP 2005 that these behaviors and actions result in a greater ability of the organization to achieve its objectives and attain higher levels of performance. The term "market orientation" refers to the extent that an organization uses the marketing concept; Kohli and Jaworski describe the processes required to engender a market orientation as a "distinct form of sustainable competitive advantage" (1990). They state that market orientation consists of "the organizationwide generation, dissemination, and responsiveness to market intelligence" (1990). Narver and Slater agreed with Kohli and Jaworski, proposing three behavioral components (customer orientation, competitor orientation, interfunctional coordination) that "comprehend the activities of marketing information acquisition and dissemination and the coordinated creation of customer value" (1990).

This study is an extension of previous research (Webster, Hammond, and Harmon 2005; Hammond, Webster, and Harmon 2006; Webster and Hammond 2011), which provided a comparison of the market orientation components to criteria for performance excellence described in the BNQP 2005. Specifically, the criteria require that an educational organization maintain an awareness of and act on the current and future needs of its customers and other stakeholders. They also require the organization to know its strengths, weaknesses, and performance levels relative to competitors, and to support a coordination of effort throughout the organization (toward creating, delivering, and "balancing" customer-stakeholder value and toward achieving high levels of customer-stakeholder satisfaction). The criteria further require an organizational wide effort to gather, disseminate, and act on information regarding the requirements, expectations, and preferences of students and other stakeholders. The BNQP 2005 suggests that students are the key customers of higher education, and suggests that parents and employers of graduates can also be considered "customers" or "stakeholders." We therefore investigate these organizational 
behaviors described in the market orientation literature as well as the BNQP 2005 as applied toward students by the accounting department chairs of AACSB member schools.

\section{RESEARCH QUESTIONS}

The objectives of this study are to answer the following research questions:

1. What are the mean levels of market orientation toward students as reported by accounting department chairs of business schools belonging to AACSB?

2. How do the mean levels of market orientation of the accounting chairs toward students compare to the levels of market orientation toward customers reported by specialty business managers as catalogued in previous research conducted on businesses in the private sector?

3. What are the mean scores of the business schools organizational performance scale as reported by the accounting department chairs?

4. Do levels of reported market orientation toward students impact the level of reported organizational performance of the business school?

To answer research question 1, market orientation mean scores of the accounting chairs are calculated for the four dimensions of market orientation (customer orientation, competitor orientation, internal coordination, and overall market orientation - the numerical average of the other three).

To answer research question 2, the mean scores of the accounting chairs are compared to the mean scores of specialty business managers as reported by Narver and Slater (1990). For each comparison, t-tests were conducted separately on the four components of market orientation.

To answer question 3, the mean scores of the organizational performance scale are computed from the inputs from the accounting department chairs.

To address question 4, regression models are constructed and analysis of variance of the regression models is undertaken to determine if the independent variables, those being the three constructs of market orientation (customer orientation, competitor orientation, and interfunctional coordination), have a significant statistical effect on the dependent variable, organizational performance of the business school.

\section{METHODOLOGY}

Data for the study were collected by way of a mailed survey. Survey instruments along with a cover letter were mailed to accounting department chairs of schools of business located in the United States holding accreditation from AACSB-International - 469 in all. The accounting chairs were asked to complete the surveys and return them in business reply envelopes that were provided. Of the total survey instruments mailed, 101 were completed and returned resulting in a response rate of $21.5 \%$.

To measure market orientation, we chose Narver and Slater's (1990) construct (MKTOR), which consists of several questions addressing specific behaviors and activities which, together, measure the extent that the organization (the school, in this case) applies the marketing concept. The scale addresses concerns raised by Barksdale and Darden (1971) that market orientation is properly measured in terms of behaviors and activities instead of "philosophical notions." A seven point response scale is used ranging from one (1) "not at all" to seven (7) "to an extreme extent."

Scores above the midpoint (4.0) indicate application by the respondent of the marketing concept; scores below the midpoint indicate a lack of application by the respondent. Questions from the original scale were modified somewhat to conform to the vocabulary prevalent in academic institutions and, as noted above, to avoid referring to students as "markets" or "customers." We combine the questions to form three subscales that measure the market orientation components (customer orientation, competitor orientation, and interfunctional coordination), matching Narver and Slater's methodology. The subscales combine to form an overall measure of market orientation, also 
matching Narver and Slater's methodology. 15 questions were used in the collection of the market orientation data. The questions and explanatory information about the survey questions may be found in appendix 1 .

"Overall performance" is measured using the subjective Jaworski and Kohli (1993) two-item measure that is based on executive opinion of performance. No specific performance goals are assumed for the respondents. Each respondent is requested to answer the two questions about actual recent overall performance relative to the expectations and performance goals of their organization, in this case the school of business. Possible responses on the seven point scale range from poor (1) to excellent (7). The questions and explanatory information about the survey questions may be found in appendix 2 . Both scales used in the research were previously vetted for validity and reliability (see Hammond, Webster, \& Harmon, 2006).

Slater and Narver (1994) defend the use of subjective performance measures, noting that the measures "are used commonly in research on private companies or business units of large corporations" as well as the "strong correlation between subjective assessments and their objective counterparts" indicated in previous research.

The possibility of nonresponse bias was investigated by comparing early and late respondents (Armstrong and Overton 1977). The tests indicated no significant differences between early and late respondents (at the .10 level of significance). Also, Berdie (1989) found that, even in the event of nonresponse bias in mail surveys, typically the bias did not alter the survey findings. We proceeded on the basis that significant nonresponse bias did not exist.

As a baseline for comparison we use Narver's and Slater's (1990) reported market orientation scores for specialty businesses. The specialty business firms produce and sell products that are individualized for specific customer orders. By adapting its generic or base product, the specialty products firm creates superior value and thereby provides more benefit to the customer. This type of firm is challenged to constantly monitor the competitive environment and to be vigilant for changes in the customer requirements. Likewise AACSB schools of business seek to provide a product that is individualized through its programs of study or its majors. AACSB schools would argue that a superior product (relative to non-member schools) is provided that would benefit its customers (or students).

\section{RESULTS}

Table 1 presents the mean score and standard deviation for the three market orientation constructs and the mean score and standard deviation for the overall market orientation score (the arithmetic average of the three component scores) as well as the mean score and standard deviation for the performance indicator. All scores are compiled from the data received from the accounting chairs. The information in this table provides answers to research questions 1 and 3 .

\section{Table 1}

Descriptive Statistics

Mean Scores For Market Orientation Constructs (3), Overall Market Orientation, And Performance Indicator For AACSB Accounting Chairs (7 Point Scales)

\begin{tabular}{lccc}
\hline Description & Mean & Std. Dev. & N \\
\hline MO-Customer & 4.439 & .9788 & 101 \\
MO-Competition & 3.383 & 1.284 & 101 \\
MO-Coordination & 3.701 & 1.157 & 101 \\
MO-Overall & 3.841 & 1.167 & 101 \\
PERFORMANCE & 5.282 & 1.004 & 101 \\
\hline
\end{tabular}

Table 2 presents the results of four separate t-tests undertaken to determine if statistically significant differences exist between the mean scores, associated with the components of market orientation, of business managers and accounting department chairs. As can be seen in the table, the business managers reported higher levels for each of the three constructs as well as for overall market orientation. The business managers reported higher scores in absolute terms than did the accounting department chairs and in each of the four t-tests, the scores were found to be different by a statistically significant margin. The information in Table 2 answers research question 2. 
Table 2

Means And T-Test Results For Accounting Department Chairs Versus Specialty Business Managers Market Orientation Measurements (7 Point Scale)

\begin{tabular}{lll}
\hline Market Orientation Construct: & $\begin{array}{l}\text { Business } \\
\text { Managers } \\
\mathbf{n = 7 5}\end{array}$ & $\begin{array}{l}\text { Accounting } \\
\text { Chairs } \\
\mathbf{n = 1 0 1}\end{array}$ \\
\hline & Mean & Mean \\
Customer Orientation & 5.05 & $4.44^{*}$ \\
Competitor Orientation & 4.71 & $3.38^{*}$ \\
Interfunctional Coordination & 4.53 & $3.70^{*}$ \\
Overall Market Orientation & 4.77 & $3.84^{*}$ \\
\hline
\end{tabular}

*significant at .01 compared to Business Managers

The regression models developed to answer research question 4 were:

$\mathrm{Y}=\mathrm{b}_{0}+\mathrm{b}_{1} \mathrm{x}_{1}+\mathrm{b}_{2} \mathrm{x}_{2}+\mathrm{b}_{3} \mathrm{x}_{3}$ where:

$\mathrm{Y}=$ mean score of the two-item performance scale as reported by the accounting department chairs $\mathrm{b}_{0}=$ intercept

$\mathrm{x}_{1}=$ mean score of the customer orientation construct as reported by the accounting department chairs $\mathrm{x}_{2}=$ mean score of the competitor orientation construct as reported by the accounting department chairs $\mathrm{x}_{3}=$ mean score of the interfunctional coordination construct as reported by the accounting department chairs

and,

$\mathrm{Y}=\mathrm{a}+\mathrm{b}_{1} \mathrm{x}_{1}$ where:

$\mathrm{Y}=$ mean score of the two-item performance scale as reported by the accounting department chairs $\mathrm{a}=$ intercept

$\mathrm{x}_{1}=$ mean score of the customer orientation construct as reported by the accounting department chairs

The simple regression model was constructed for two specific reasons. First, the coefficient of the customer orientation construct in the multiple regression was found to be statistically significant. Secondly, as was mentioned earlier in the paper, a mean score above the midpoint of the scale ( 4.0 in this case) is indicative of the application of the marketing concept.

Tables 3 and 4 that follow present the results of the analysis of variance of the two regression equations and yield that both the regression models are statistically significant in that both show that organizational performance is positively affected by higher market orientation scores in the first instance and singularly by customer orientation scores in the case of the simple regression. These two models and the analysis that follow provide insight and answers to research question 4 .

Table 3

F-Test Results From The

Analysis Of Variance Of The Multiple Regression Model

Market Orientation Effects On Performance Of Business Schools As Reported By Accounting Department Chairs

\begin{tabular}{lll}
\hline Source & F & Significance \\
\hline Model & 13.592 & .000 \\
MO/Customer & 4.184 & .044 \\
MO/Competitor & 8.685 & .004 \\
MO/Coordination & 0.141 & .708 \\
\hline
\end{tabular}

R Squared=.296 (Adjusted R Squared=.274) 
Table 4

F-Test Results From The

Analysis Of Variance Of The Simple Regression Model

Customer Orientation Effect On Performance Of Business Schools

As Reported By Accounting Department Chairs

\begin{tabular}{lll}
\hline Source & F & Significance \\
\hline Model & 28.847 & .000 \\
MO/Customer & 28.847 & .000 \\
\hline
\end{tabular}

R Squared=.226 (Adjusted R Squared=.218)

\section{CONCLUSIONS AND IMPLICATIONS}

This research finds that customer and market orientation do indeed affect organizational performance at least as reported by the accounting department chairs. Higher levels of both the customer orientation construct and the three construct market orientation model are both significant models (variables) in explaining changes in levels of reported performance. The research findings also demonstrate that businesses perceive a greater importance and have made greater progress in the implementation of the marketing concept vis-à-vis university schools of business as perceived by their academic accounting department chairs. This research found, as has previous research conducted on business organizations, that organizations may improve their performance by increasing levels of customer and market orientation.

The accounting department chairs reported lower levels of market orientation in their organizations than did their business counterparts. This may signal that the accounting department chairs are either not familiar with the marketing concept, customer and market orientation, or reject the idea that students are customers of the school, or all of the above. However, a significant opportunity would seem to exist to improve performance for schools that will put more effort into customer and market orientation. Since students of the university may be viewed as the most visible of the numerous markets served, customer and market orientation efforts focused at students would seem to have the potential for the fastest and highest payoff. Examples of such payoffs, all of which might correctly be viewed as performance indicators might include:

1. A potential increase in enrollment within the school of business

2. A potential increase in the hit rate (increase in percent of applicants that actually enroll)

3. A potential increase in the number of business/accounting majors

4. A potential increase in the retention rate of business/accounting students

5. A potential increase in the graduation rate of current business/accounting students

6. A potential improvement in rankings by outside organizations

Our conclusions are tempered by the findings of Noble, Sinha, \& Kumar (2002) and Haugland, Myrtveit, \& Nygaard (2007) that there appears to be no single strategic orientation that leads to superior performance in every case; and as previously stated, building a market orientation culture within an organization is not a quick fix but rather a continuous process.

\section{FUTURE RESEARCH}

The research we report leaves open several related areas of interest for additional study. For example, do customer and market orientation levels vary between different levels of administrative responsibility within the business school or university at large? Also, research on other stakeholders such as parents of students, employers of students, and alumni associated with schools of business would be useful. Such research would further our understanding of the market orientation construct and its application to higher education. Finally, research should be conducted to determine if a market orientation culture has an impact on specific performance measures such as student retention and graduation rates. 


\section{AUTHOR INFORMATION}

Robert L. Webster, Ouachita Baptist University. Dr. Webster holds the George Young Endowed Chair of Business and also serves as the Chairperson of the Accounting Department. He is a former President of the Southwest Region of the American Accounting Association. His research interests are in behavioral studies in business as well as financial analysis. E-mail: websterb@obu.edu (Corresponding author)

Kevin L. Hammond, University of Tennessee at Martin. Dr. Hammond is professor of Marketing and also serves as the Graduate Program Advisor for business graduate programs at the University of Tennessee at Martin. He has published widely in the marketing literature with his most recent research dedicated to the subject of market orientation within higher education. E-mail: khammond@utm.edu

James C. Rothwell, Ouachita Baptist University. Mr. Rothwell serves as the assistant dean of the business school. He is a Certified Public Accountant and has served in numerous internal audit positions. E-mail: rothwellj@obu.edu

\section{REFERENCES}

1. Armstrong, J. S. \& Overton, T. S. (1977) Estimating nonresponse bias in mail surveys. Journal of Marketing Research, 14 (August), 396-402.

2. Barksdale, H. C. \& Darden, B. (1971) Marketers attitude toward the marketing concept. Journal of Marketing, 35 (October), 29-36.

3. Bentler, P. M. (1990) Comparative fit indexes in structural models. Psychological Bulletin, 107, 238-246.

4. Bentler, P. M. \& Bonett, D. G. (1980) Significance tests and goodness of fit in the analysis of covariance structures. Psychological Bulletin, 88, 588-606.

5. Berdie, D. (1989) Reassessing the value of high response rates to mail surveys. Marketing Research, 1, 5264.

6. BNQP (2005), "Baldrige Education Criteria for Performance Excellence," Baldrige National Quality Program, www.quality.nist.gov/Education_Criteria.htm

7. Browne, M. W. \& Cudeck, R. (1993) Alternate ways of assessing model fit. In Bollen, K. A. \& Long, K. S. (Eds.) Testing structural equation models. Newbury Park, California: Sage, 136-162.

8. Browne, M. W. \& Mels, G. (1992) RAMONA User's Guide. The Ohio State University, Columbus, Ohio.

9. Churchill, G. A. (1979) a paradigm for developing better measures of marketing constructs. Journal of Marketing Research, 16 (February), 64-73.

10. Dwyer, F. R., \& Welsh, M. A., (1985) Environmental relationships of the internal political economy of marketing channels. Journal of Marketing Research, 22, (November), 397-414.

11. Felton, A. P. (1959) Making the marketing concept work. Harvard Business Review, 37, (July-August), 5565 .

12. Hammond, K L., Webster, R. L., \& Harmon, H. A., (2006) Market orientation, top management emphasis, and performance within university schools of business: implications for universities. Journal of Marketing Theory and Practice, (Winter), Vol. 14, No. 1, 69-85.

13. Haugland, S.A., Myrtveit, I., \& Nygaard, A. (2007) Market orientation and performance in the service industry: A data envelopment analysis. Journal of Business Research Vol. 60 No. 11, (Nov). 1191-1197.

14. Houston, F. S. (1986) The marketing concept: what it is and what it is not. Journal of Marketing, 50 (April), 81-87.

15. Hunt, S. (1990) Commentary on an empirical investigation of a general theory of marketing ethics. Journal of the Academy of Marketing Science, 18, (Spring), 173-177.

16. Jaworski, B. J. \& Kohli, A. K. (1993) Market orientation: antecedents and consequences. Journal of Marketing, 57 (July), 53-70.

17. Karathanos, D. \& Karathanos, P. (1996) The Baldridge education pilot criteria 1995: An integrated approach to continuous improvement in education. Journal of Education for Business, 71 (May/June), 272276.

18. Kohli, A. K. \& Jaworski, B. J. (1993) Market orientation: the construct, research proposition, and managerial implications. Journal of Marketing, 54 (April), 1-18. 
19. Kotler, P. (1980) Marketing Management: Analysis. Planning and Control, (4th ed.) Englewood Cliffs, NJ: Prentice-Hall, Inc.

20. Larson, R. \& Catton, W., Jr. (1959) Can the mail-back bias contribute to a study's validity? American Sociological Review, XXIV, 243-245.

21. Levitt, T. (1969) The Marketing Mode. New York: McGraw-Hill Book Company.

22. Marsh, H. W. \& Hocevar, D. (1985) Applications of confirmatory factor analysis to the study of selfconcept: first -and higher-order factor models and their invariance across groups. Psychological Bulletin, 97, 562-582.

23. McNamara, C. P. (1972) The present status of the marketing concept. Journal of Marketing, 36 (January), 50-57.

24. Morse, R. J. \& Flanigan, S. M. (2000) America's best colleges-how we rank them. U.S. News and World Report, (September 11), 104-105.

25. Narver, J. C., Park, S. Y. \& Slater, S. F. (1992) Market orientation, information, and marketing strategies. American Marketing Association Summer Educators Conference.

26. Narver, J. C. \& Slater, S. F. (1990) The effect of a market orientation on business profitability. Journal of Marketing, 54 (October), 20-35.

27. Noble, C. H., Sinha, R. J., \& Kumar, A. (2002) Market orientation and alternative strategic orientations: a longitudinal assessment of performance implications. Journal of Marketing, 66 (October), 25-39.

28. Peterson's Guide to Four Year Colleges, 2001, 31st ed. (2000) Lawrenceville, NJ: Peterson's/Thomson Learning.

29. Siguaw, J. A., Brown, G. \& Widing, R. E., II, (1994) The influence of the market orientation of the firm on sales force behavior and attitudes. Journal of Marketing Research, 31 (February), 106-116.

30. Slater, S. F. \& Narver, J. C. (1994) Does competitive environment moderate the market orientationperformance relationship? Journal of Marketing, 58 (January), 46-55.

31. Webster, R.L., Hammond, K.L., \& Harmon, H.A. (2005) Comparing market orientation culture of businesses and schools of business: an extension and refinement. Psychological Reports, 96, 377-382.

32. Webster, R.L. \& Hammond K.L. (2011) An organizational performance study of AACSB International member business schools. American Journal of Business Education, Vol 5-1, 1-10.

33. Wheaton, B., Muthen, B., Alwin, D. F., \& Summers, G. F. (1977) Assessing reliability and stability in panel models. In Heise, D. R. (Ed.) Sociological Methodology 1977. San Francisco: Jossey-Bass, 84-136. 


\section{APPENDIX 1}

Market Orientation Survey Questions Sent to

Accounting Department Chairs of AACSB Schools of Business

1. Our objectives are driven by satisfaction of our students.

2. We measure satisfaction of our students systematically and frequently.

3. Those responsible for recruiting students regularly share information within our business school/institution concerning competitor's strategies.

4. Our market strategies (such as recruiting and retention) are driven by our understanding of the possibilities for creating value for our students.

5. We respond rapidly to competitive actions that threaten us.

6. We constantly monitor our level of commitment and orientation to students.

7. University administration regularly discusses competitors' strengths and strategies.

8. All levels of administration understand how the entire institution can contribute to creating value for students.

9. We give close attention to service of students after enrollment.

10. Our strategy for competitive advantage is based on our understanding of our students needs.

11. We encourage other staff and faculty outside of recruiting/administration to meet with our prospective students.

12. All of our departments are responsive to and integrated in serving students.

13. Information on recruiting successes and failures are communicated across functions in the business school/institution.

14. We share information and coordinate resource use with other units in the institution.

15. We target potential students where we have, or can develop a competitive advantage.

Each question answered on a 7 point scale: 1=Not At All, 7=To An Extreme Extent. Questions 1, 2, 4, 6, 9, and 10 relate to the Customer Orientation construct/dimension, Questions 3, 5, 7, 11, and 15 relate to the Competitor Orientation, Questions 8,12,13, and 14 relate to Organizational Coordination. The Overall Marketing Orientation score is computed by averaging the mean scores of the other three sets of questions. 


\section{APPENDIX 2}

Performance Measurement Questions Sent to Accounting Department Chairs of AACSB Schools of Business

1. Overall performance of the school of business last year was.

2. Overall performance of your school of business relative to major competitors last year was.

Both questions answered on a 7 point scale: 1=Poor, 7=Excellent 